\title{
Cannabidiol Induces Cytotoxicity and Cell Death via Apoptotic Pathway in Cancer Cell Lines
}

\author{
Won Hyung $\mathrm{CHOI}^{1 *}$, Hyun Do Park ${ }^{2}$, Seung Hwa BaEK ${ }^{3}$, Jong Phil $\mathrm{CHU}^{1}$, \\ Mae Hwa KANG ${ }^{1}$ and Yu Jing Mı ${ }^{1}$ \\ ${ }^{1}$ Department of Medical Zoology, College of Medicine, KyungHee University, \\ \#1 Hoegi-dong, Dongdaemun-gu, Seoul 130-701, Korea \\ ${ }^{2}$ Division of Anatomy \& Developmental Biology, Department of Oral Biology, BK21 Project, \\ College of Dentistry, Yonsei University, 134 Shinchon-dong, Seodaemoon-gu, Seoul 120-752 and \\ ${ }^{3}$ Department of Herbal Resources, Professional Graduate School of Oriental Medicine, \\ Wonkwang University, Iksan 570-749, South Korea
}

(Received April 10, 2008; Accepted May 22, 2008)

\begin{abstract}
In view of obtaining potential anticancer compounds, we studied the inhibitory activity and the cytotoxic effects of a candidate compound in cancer cells. The cytotoxic effects of cannabidiol (CBD) in vitro were evaluated in NIH3T3 fibroblasts, B16 melanoma cells, A549 lung cancer cells, MDA-MB-231 breast cancer cells, Lenca kidney cells and SNU-C4 colon cancer cells. The cells were cultured in various concentrations of CBD for $48 \mathrm{~h}$ and $25 \mu \mathrm{M}$ of CBD for 6-36 $\mathrm{h}$. The cells were observed to exhibit inhibitory effects of the cell viability in their growth, and then cytotoxicity was estimated. The inhibitory activity of CBD was increased in all cancer cells and showed especially strong increment in breast cancer cells. The cytotoxicity of CBD increased in a dose- and time-dependent manner with growth inhibition in all cancer cell lines. Also, to assess the membrane toxicity induced by CBD, we investigated lactate dehydrogenase (LDH) release. After treatment with various concentrations of CBD, LDH release rate of cancer cells was accelerated. On the other hand, in the induction of cell death, caspase- $3,-8$ and -9 activations were detected in cancer cells after treatment with various concentrations of CBD, and CBD effectively induced activity of caspase-3, -8 and -9 in A549 lung cancer cells, MDAMB-231 breast cancer cells and Renca kidney cells. Therefore these results suggest that CBD has a possibility of anticancer agents and anticancer effects against cancer cells by modulation of apoptotic pathway in the range of 5-80 $\mu \mathrm{M}$ concentration.
\end{abstract}

Keywords: Cannabidiol, Cytotoxicity, LDH release, Caspase, Breast cancer cells

\section{INTRODUCTION}

For the biological study on cannabidiol (CBD), we investigated the cytotoxic effects of CBD against cancer cells. New herbal medicines containing drug and medicinal properties for controlling cancer cells are found in medicinal plants and studied. In this aspect, research groups in many countries are researching on plant extracts and chemical compounds related to medicinal plants. Cannabis sativa $\mathrm{L}$. is one of the cultivated plants for a long time from old times. It was used as a resource

\footnotetext{
${ }^{*}$ Corresponding author

Tel: +82-2-961-0278, Fax: +82-2-967-8401

E-mail: whchoi@khu.ac.kr
}

of fiber and a remedy in West Asia region and China from several thousands years ago, and was introduced into Western and Southern Europe. However, Cannabis sativa L. (Cannabis) has been an intoxicant plant in the western world during the 20th century and now, it is restricted as one of the illicit drugs. Cannabis consists of several hundreds of varieties and is not a single uniform plant. Chemical variants through Cannabis have been identified by their content of psychoactive compounds. Cannabis is a generic name for variety of botanical specimen derived from the plant Cannabis sativa L., and contains more than 200 cannabinoid substances, including delta-9-tetrahydrocannabinol (THC) (Pertwee, 1997). Potential therapeutic applications of cannabis include analgesia, attenuation of the nausea, vomiting of cancer 
chemotherapy, increase of stimulation, decrease of diarrhea, decrease of asthma by bronchial constriction, decrease of intraocular pressure by glaucoma, anti-rheumatic and anti-pyretic action, and treatment of convulsant disorders. These effects were reviewed by Asakawa et al., 1995 and Perry et al., 1996. The cannabinoid, cannabidiol compound, and the active constituents of Cannbis sativa $L$. have been known to affect many biological systems (Carrier et al., 2006; Esposito et al., 2006; Garcia-Arencibia et al., 2007; Giudice et al., 2007; Martin, 1986; Weiss et al., 2006). Cannbis sativa L. exhibits antitumor effects on various cancer cell types (Ligresti et al., 2006; Mckallip et al., 2006), but it is used only in the chemotherapy which is limited by psychotropic therapy. Cannabidiol has been reported to operate potentially important pharmacological properties as an anti-epileptic (Consroe et al., 1981), anxiolytic (Guimaraes et al., 1990) and anti-convulsant agent (Martin et al., 1987; Consroe et al., 1982). Many natural products express various activities in the cell death pathway. In the cell death process, activation of mediated proteins operates via apoptotic signal inclusive of mediated cascade-pathway mechanism. One of the enzymatical characteristics of the cell deaths, caspases are the important proteins involved in regulating the activation of apoptotic signal transmission, and caspase- 3 is the cell death signal protein activated by caspase-8, -9 of upstream. Chemical structure of Cannabidiol tested is shown in Fig. 1. The aim of our study is to estimate cytotoxic activity and growth inhibition against cancer cell lines, and to find out a new superior compound. In this aspect, we investigated cytotoxic effects of cannabidiol compound against cancer cell lines.

\section{MATERIALS AND METHODS}

\section{Materials}

Fetal bovine serum (FBS), RPMI medium 1640, DMEM medium, 3-(4,5-dimethythiazol-2-yl)-2,5-diphenyl-2H-tetrazolium bromide (MTT), dimethyl sulfoxide (DMSO), trypsinEDTA, $0.4 \%$ trypan blue solution, penicillin, and the LDH

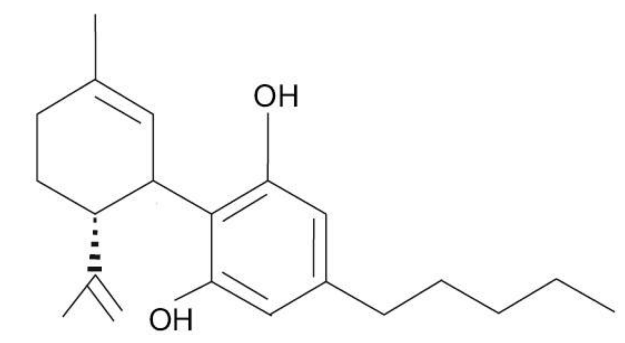

Fig. 1. Chemical structure of cannabidiol (CBD) activity kit were purchased from Sigma Chemical Co. Ltd. (St. Louis, MO, USA). The caspase-3 kit (FLICA ${ }^{\text {TH }}$ FAMDEVD-FMK), caspase-8 kit (FLICA ${ }^{\text {TH }}$ FAM-LETD-FMK) and caspase-9 kit (FLICA ${ }^{\text {TH }}$ FAM-LEHD-FMK) were purchased from Immunochemistry Technologies, LLC (James Ave. Bloomington, MN, USA). Cancer cell lines were obtained from the Korean Cell Line Bank at Seoul National University. All other chemicals and reagents were purchased from Merck and Sigma Chemical Co. Ltd. (St. Louis, MO, USA).

\section{Cell culture}

Cancer cells lines were obtained from the Korean Cell Line Bank at Seoul National University. Cells were cultured in RPMI medium 1640 or DMEM medium containing $2 \mathrm{mM}$ L-glutamine, supplemented with $10 \%$ fetal bovine serum (FBS), penicillin 100 units $/ \mathrm{ml}$ and streptomycin $100 \mu \mathrm{g} / \mathrm{ml}$ (Biofluids, Rockville, MD, USA) in a humidified atmosphere containing $5 \% \mathrm{CO}_{2}$ in air at $37^{\circ} \mathrm{C}$. The cells were dissociated with trypsin-EDTA $(0.05 \%$ trypsin, $0.53 \mathrm{mM}$ EDTA, Gibco, USA) and were counted with a hemocytometer just before transferring them for the experiment.

\section{MTT assay on cell viability}

Cell growth in the presence of Cannabidiol (CBD) was determined by an MTT (3-(4,5-dimethythiazol-2-yl)-2,5diphenyl-2H-tetrazolium bromide; Thiazolyl blue) assay. This assay was performed as described in the modified method of Mosmann (Mosmann, 1983). Cells were seeded in a 96-well micro-multiculture plate at $4 \times 10^{4}$ cells per well and allowed to adhere overnight. Cells were cultured that exposed to various concentrations of $\mathrm{CBD}$ for $48 \mathrm{~h}$ and $25 \mu \mathrm{M}$ of CBD for 6-36 h. MTT was prepared at a concentration of $5 \mathrm{mg} / \mathrm{ml}$ using a sterile phosphate buffered saline (PBS) system. A $50 \mu \mathrm{l}$ aliquot of the stock solution of MTT $(100 \mu \mathrm{g} / \mathrm{ml})$ was added to each well. After $3 \mathrm{~h}$ of incubation at $37^{\circ} \mathrm{C}, 150 \mu \mathrm{l}$ of DMSO was added to each well in order to dissolve the formazan crystals. Optical absorbance was measured at a wavelength of $570 \mathrm{~nm}$ using an ELISA reader (Molecular Devices, Spectra MAX 250, USA). Each well containing RPMI 1640 medium or DMEM medium, MTT buffer in the absence of cells was used as the blank. All results obtained were calculated from three experiments and presented as a percentage of control values. The value of $\mathrm{IC}_{50}$ which annihilated the $50 \%$ compared control cells is the concentration of $\mathrm{CBD}$ that inhibits the proliferation of cancer cells. There was good reproducibility among triplicate determinations. 


\section{Lactate dehydrogenase (LDH) assay}

The LDH release assay measures the leakage of the soluble cytoplasmic lactate dehydrogenase enzyme into the extracellular medium due to cellular lysis. To watch the characteristic showed during the progress of the cell deaths in the cancer cell, we measured the effects of $\mathrm{CBD}$ on the cancer cells using the LDH release assay. Namely, when cells were cultured with CBD for $24 \mathrm{~h}$, cancer cells' viability was measured by the release of the cytosolic enzyme and LDH from cells. The activity of LDH released was measured using in Sigma Kit according to the manufacturer's measurement directions.

\section{Caspase-3, $-8,-9$ activity assay}

Cancer cell lines were cultured with CBD in a 96-well micro-multiculture plate at $5 \times 10^{5}$ cells per well for various times, and with various concentrations $(25 \mu \mathrm{M})$ for 24 h. A fluorescent assay was used to measure caspase- $3,-8$ and -9 activities. The enzymatic reaction for caspase- $3,-8$ and -9 activity was determined by using the caspase- $3,-8$ and -9 assay kit according to the instructions supplied by the manufacturer. Cells were labeled with FAM-DEVDFMK (caspase-3), FAM-LETD-FMK (caspase-8) and FAM-LEHD-FMK (caspase-9) solution at $37^{\circ} \mathrm{C}$ for $60 \mathrm{~min}$, and the fluorescent optical density of the assay solution was detected with excitation at $490 \mathrm{~nm}$ and emission at $520 \mathrm{~nm}$.

\section{Statistical analysis}

All data are expressed as the mean \pm standard deviation (S.D.) of the three independent experiments. Statistical analysis was performed using student's $t$-test. The differences were considered significant at ${ }^{\star} P<0.05$.

\section{RESULTS}

\section{Inhibitory effect on cell viability}

Many research groups have used the MTT assay based on the metabolic reduction to evaluate the drug effects in cell viability or cytotoxicity. This assay is a method of examining the level of cytotoxicity and measuring the mitochondrial activity of cells, and then shows us the result of the cell viability. We used the MTT assay as a direct measure of cell viability and cytotoxicity in cancer cells exposed to various concentrations of CBD. The cells were incubated with various concentrations of $\mathrm{CBD}$ from $5 \mu \mathrm{M}$ to $80 \mu \mathrm{M}$ for $48 \mathrm{~h}$ and $25 \mu \mathrm{M}$ of CBD for 6-36 h. As shown in Fig. 2, CBD strongly inhibited the viability of cancer cells. Notably, the $\mathrm{IC}_{50}$ for viability of MDA-MB231 cells treated with CBD was $29.04 \mu \mathrm{M}$ (Table I). The
(A)

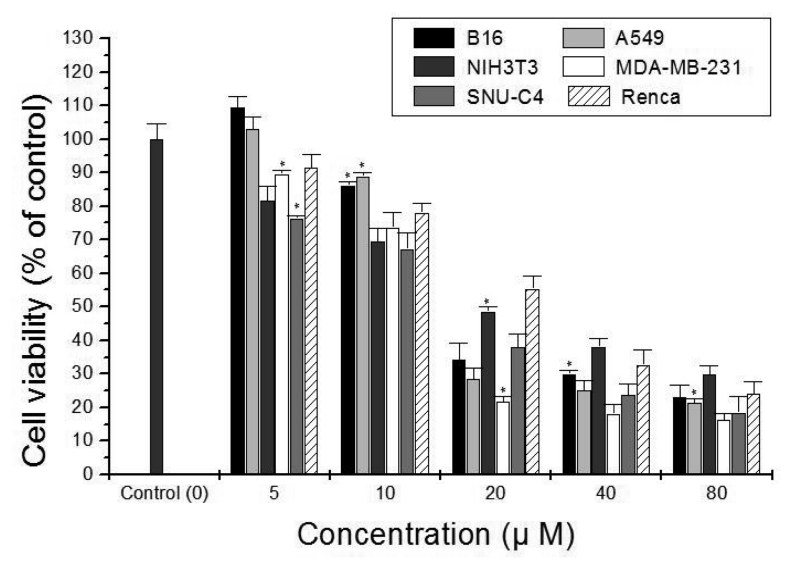

(B)

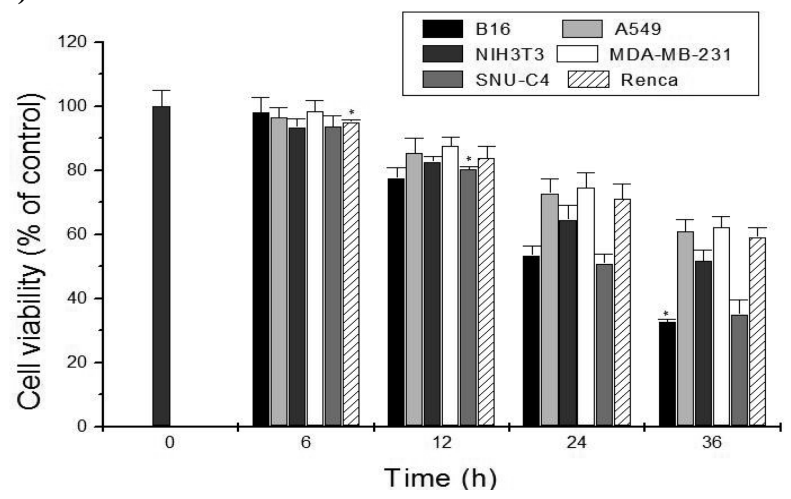

Fig. 2. Inhibitory effects of $\mathrm{CBD}$ on cell viability in cancer cell lines by the MTT assay. (A); The cells were cultured in the presence of various concentrations of CBD for $48 \mathrm{~h}$ and $(\mathrm{B})$; in $25 \mu \mathrm{M}$ concentration of $\mathrm{CBD}$ for 6-36 h. NIH3T3 is fibroblast normal cells, B16; melanoma cells, A549; lung cancer cells, MDA-MB-231; breast cancer, Renca; kidney cancer cells, and SNU-C4; colon cancer cells. Results are expressed as a \% of the control and data are the mean \pm S.D. of three experiments performed in triplicate. ${ }^{*} P<0.05$, significant versus control untreated cells.

CBD-induced cytotoxicity increased in a dose- and timedependent manner when CBD was increased from $5 \mu \mathrm{M}$ to $80 \mu \mathrm{M}$, and was treated to $25 \mu \mathrm{M}$ for 6-36 h. These results show that cancer cells exposed with various concentrations of CBD caused the morphological changes of apoptosis including a feature of cell shrinkage, formations of cell protuberance and the change of membrane bleb (Fig. 3). Therefore, these results show that the viability of cancer cells decreased in a dose- and time-dependent manner by CBD.

\section{Effects of CBD on LDH release}

$\mathrm{NIH} 3 \mathrm{T3}$ and cancer cells exposed with $5-80 \mu \mathrm{M}$ of 

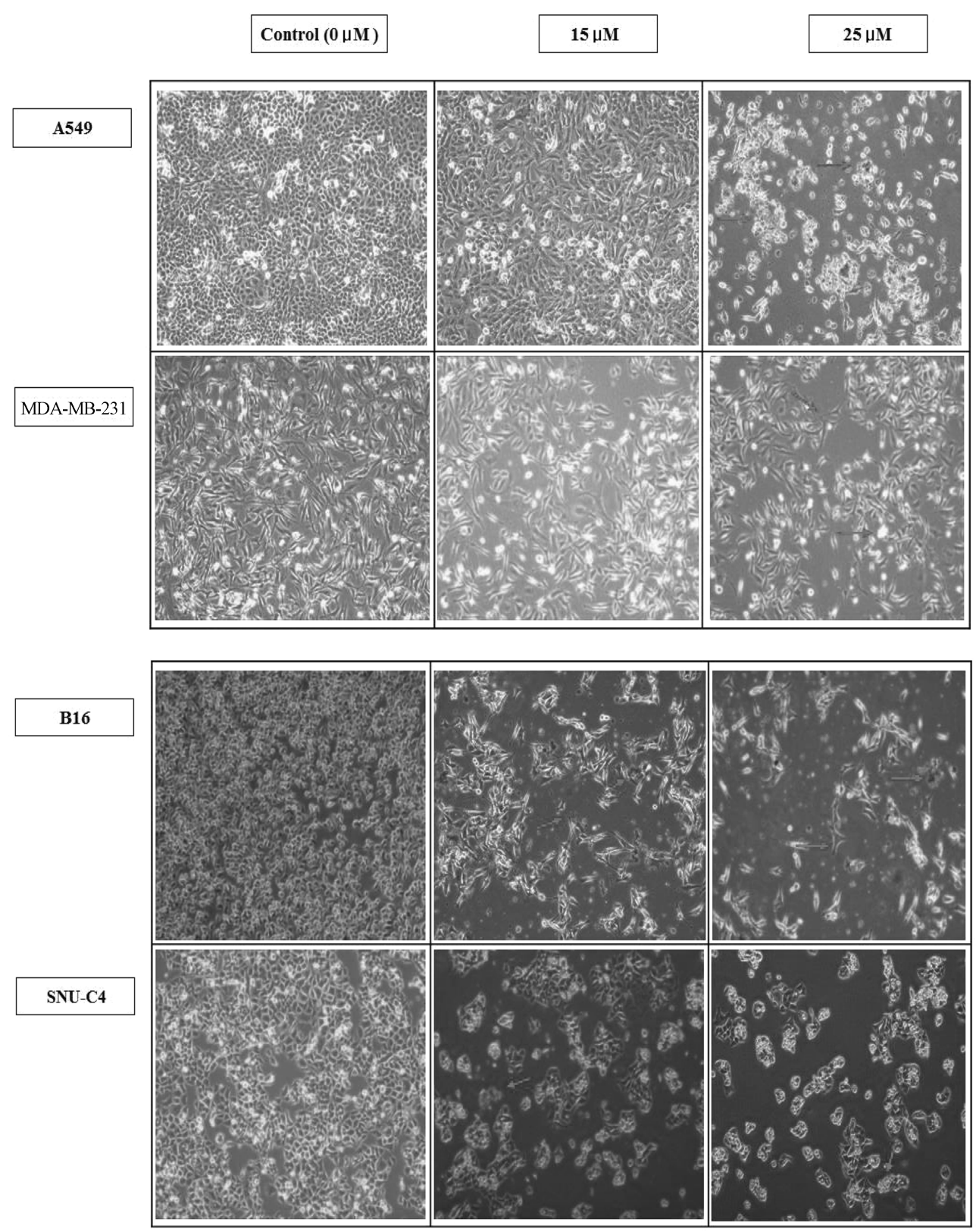

Fig. 3. Morphological changes of cancer cell lines exposed to various concentrations of CBD for $48 \mathrm{~h}$. The arrow $(\leftarrow)$ shows the morphological changes including a feature of cell shrinkage, formations of cell protuberance.

$\mathrm{CBD}$ for $24 \mathrm{~h}$ produced an obvious increase in the LDH release. The LDH release from cells is one of the indicators, a measure to estimate LDH activity and the cell death in the medium (measured spectrophotometrically as NADH oxidation at $340 \mathrm{~nm}$ ). As shown in Table II, when the cells were treated with various concentrations of $\mathrm{CBD}$ for $24 \mathrm{~h}$, the cytotoxicity of CBD was increased in a dose dependent manner, and LDH release of CBDinduced cells was increased significantly. It is the result that $\mathrm{CBD}$ inhibits the activity of the metabolism process in the cells, and then shows the cytotoxicity.

\section{Activation of caspases in cell death}

The caspase- $3,-8$ and -9 activities after $24 \mathrm{~h}$ of treatment by CBD showed a gradual increase for $0-6 \mathrm{~h}$, and appeared a tendency of the strong increase from 6-24 h, but colon cancer cells (SNU-C4) and B16 melanoma cells showed slight increase (Fig. 4A-C). The activation of caspase- $3,-8$ and -9 caused by CBD had the tendency to depend in time dependent manner in MDA-MB-231, 
Table I. $\mathrm{IC}_{50}$ values of $\mathrm{CBD}$ against cancer cell lines treated with various concentration of $\mathrm{CBD}$ for $48 \mathrm{~h}$. The cytotoxicity was determined by the MTT assay.

\begin{tabular}{cc}
\hline Constituents & MTT assay $(\mu \mathrm{M})^{\mathrm{a})}$ \\
\cline { 2 - 2 } & $\mathrm{IC}_{50}$ value of cannabidiol \\
\hline NIH3T3 & $40.78 \pm 4.21$ \\
B16 melanoma & $38.69 \pm 3.58$ \\
A549 & $36.70 \pm 4.60$ \\
Renca kidney & $54.82 \pm 4.35$ \\
MDA-MB-231 & $29.04 \pm 2.13$ \\
SNU-C4 & $32.37 \pm 2.84$
\end{tabular}

a) $\mid \mathrm{C}_{50}$ represents the concen-tration of the tested compound required for $50 \%$ inhibition of cell proliferation. NIH3T3 is fibroblast normal cells. B16; melanoma cells, A549; lung cancer cells, MDA-MB-231; breast cancer cells, Renca; kidney cancer cells, SNU-C4; colon cancer cells. Cells were examined in five concentrations of CBD in triplicate experiments. Results are expressed as a \% of the control and data are the mean \pm S.D. of three experiments performed in triplicate.

Renca and A549 cells. The caspase- 3 activity by CBD for 12-24 $\mathrm{h}$ became more active, and the amount of fluorescence was increased over $300 \%$ in CBD-induced MDAMB-231, Renca and A549 cells. Also, the caspase-9 activation showed a gradual increase for 0-6 $\mathrm{h}$ and high increase for 6-18 $\mathrm{h}$ in a time-dependent manner, even though showed the tendency to decrease as $18 \mathrm{~h}$ over. In the other cells (B16, SNU-C4) exposed, the caspase-3, -8 and -9 exhibited inactivation.

\section{DISCUSSION}

Natural products isolated from oriental plants are being investigated for their therapeutic application against many diseases such as cancer, diabetes and hypertension. Today, in the Netherlands, Cannabis sativa L. has been recognized that it has a pharmacological efficacy, and it will be permitted the sale officially in 2008-2010. Recent reports on Cannabidiol (CBD) show that it decreases proliferation activity in cancer cell lines (Casanova et al., 2003; Vaccani et al., 2005). Also, recent reports state that $\mathrm{CBD}$ is a potent inhibitor of cell growth in human breast carcinoma and human leukemia cells (Ligresti et al., 2006; Mckallip et al., 2006). This research investigated the cytotoxicity and inhibitory effects of CBD against cancer cells. As noted above, the MTT assay was used in this research to demonstrate the cytotoxic activity of CBD on cancer cell lines. CBD compound had shown an inhibitory activity in the micro-molar range against cancer cells in vitro. As shown in Fig. 2, the inhibitory activity of CBD
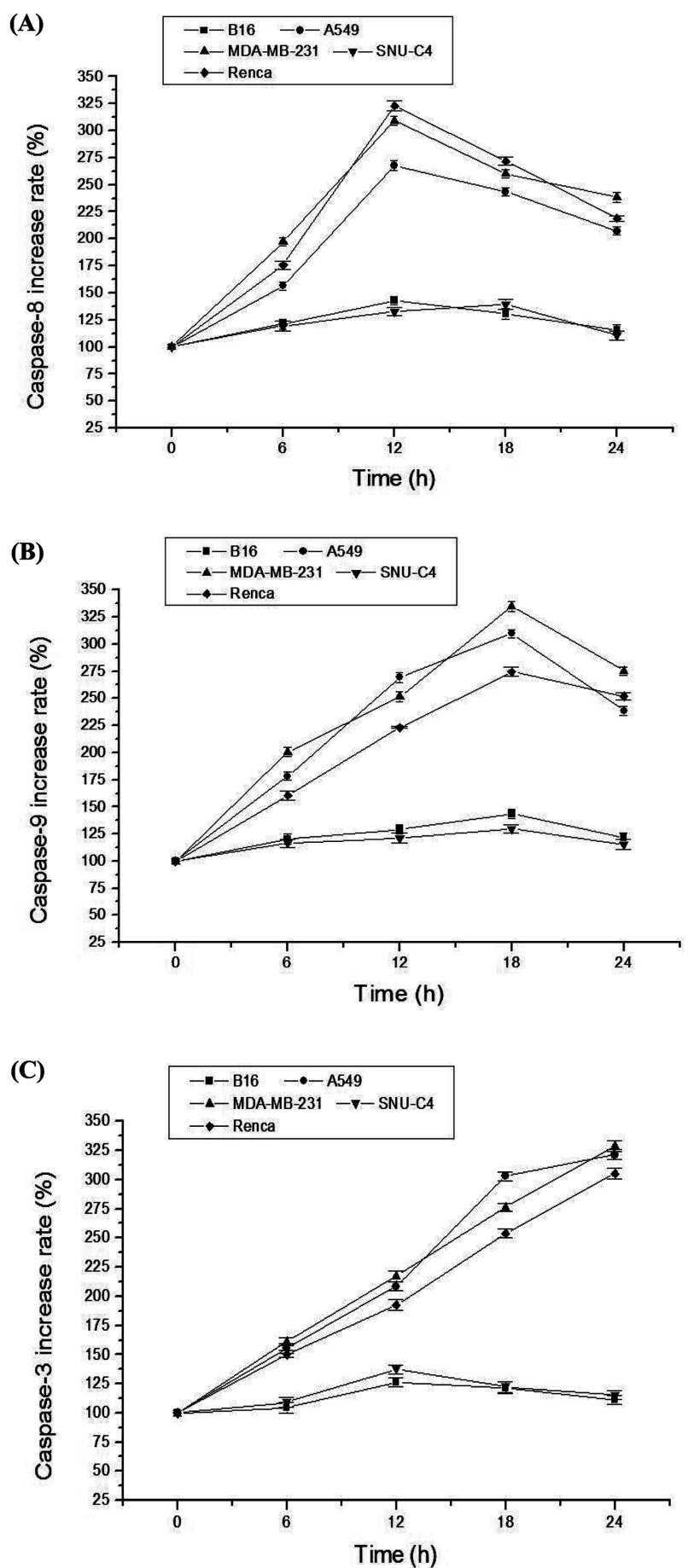

Fig. 4. Activations of caspase- $3,-8$ and -9 on apoptotic signal pathways in cancer cell lines. After treatment of CBD $(25 \mu \mathrm{M})$ for 0-24 h, cells were labeled with FAM-LETD-FMK (Caspase-8), FAM-LEHD-FMK (Caspase-9) and FAM-DEVD-FMK (Caspase3) solution for $1 \mathrm{~h}$ at $37^{\circ} \mathrm{C}$. (A); caspase-8, (B); caspase- 9 and (C); caspase-3 exhibit activity of caspase in cancer cells. Activation of caspase was detected with excitation at $490 \mathrm{~nm}$ and emission at $520 \mathrm{~nm}$. Results are expressed as a \% of the control and data are the mean \pm S.D. of three experiments performed in triplicate. 
in cell lines was increased in a concentration- and timedependent manner from $5 \mu \mathrm{M}$ to $80 \mu \mathrm{M}$ range. The number of cells was decreased when CBD was increased to $80 \mu \mathrm{M}$, and $\mathrm{IC}_{50}$ values of $\mathrm{CBD}$ on cell lines decreased in the following order: MDA-MB-231>SNU-C4>A549>B16 melanoma $>\mathrm{NIH} 3 \mathrm{~T} 3>$ Renca kidney cells by the MTT assay according to sensitivity of cells (Table I). The cytotoxic activity of CBD shown in results was the effective proof for the growth inhibition of cancer cell lines, and then $\mathrm{IC}_{50}$ value of MDA-MB-231 cells was measured as $29.04 \mu \mathrm{M}$. This $I_{50}$ value was estimated to be lowest while compared among cancer cell lines.

Apoptosis is a form of self-regulated cell death, which is distinguished from necrosis (Kerr et al., 1972). The characteristic morphological changes of apoptosis include the change of membrane bleb, chromatin condensation and the formation of apoptotic bodies. In the present study, data presented in Table II show the results of LDH leakage rates on the membrane permeability in $\mathrm{NIH} 3 \mathrm{~T} 3$ and cancer cell lines treated with CBD for $24 \mathrm{~h}$. In metabolic system of cells, LDH is a stable cytoplasmic enzyme which is present in cells, and is released into culture

Table II. Results of CBD on LDH release in NIH3T3 cells and Cancer cell lines. Cells were treated with various concentrations of CBD $(5-80 \mu \mathrm{M})$ for $24 \mathrm{~h}$.

(A)

\begin{tabular}{cccc}
\hline \multirow{2}{*}{ Constituents } & \multicolumn{3}{c}{ LDH release rates by Cannabidiol (\%) } \\
\cline { 2 - 4 } & NIH3T3 & B16 melanoma & A549 \\
\hline Control $(0 \mu \mathrm{M})$ & $100.00 \pm 2.65$ a) & $100.00 \pm 1.53$ & $100.00 \pm 3.28$ \\
5 & $107.23 \pm 3.28$ & $110.26 \pm 3.60$ & $104.55 \pm 2.36$ \\
10 & $115.58 \pm 4.50$ & $117.85 \pm 2.31$ & $107.72 \pm 3.02$ \\
20 & $136.37 \pm 2.84$ & $139.06 \pm 4.72$ & $112.35 \pm 2.13$ \\
40 & $144.26 \pm 4.35$ & $152.93 \pm 4.69$ & $119.08 \pm 3.58$ \\
80 & $158.69 \pm 3.81$ & $163.77 \pm 3.75$ & $127.69 \pm 4.32$
\end{tabular}

(B)

\begin{tabular}{cccc}
\hline \multirow{2}{*}{ Constituents } & \multicolumn{3}{c}{ LDH release rates by Cannabidiol (\%) } \\
\cline { 2 - 4 } & MDA-MB-231 & SNU-C4 & Renca \\
\hline Control $(0 \mu \mathrm{M})$ & $100.00 \pm 4.16$ & $100.00 \pm 2.58$ & $100.00 \pm 3.73$ \\
5 & $102.23 \pm 2.40$ & $108.33 \pm 3.12$ & $105.14 \pm 1.92$ \\
10 & $110.36 \pm 3.31$ & $121.30 \pm 4.36$ & $113.83 \pm 2.65$ \\
20 & $115.62 \pm 2.75$ & $129.05 \pm 4.51$ & $122.42 \pm 4.74$ \\
40 & $123.71 \pm 4.63$ & $140.21 \pm 3.62$ & $131.60 \pm 1.30$ \\
80 & $132.25 \pm 2.35$ & $154.65 \pm 3.70$ & $139.51 \pm 4.58$ \\
\hline
\end{tabular}

Results are expressed as a \% of the control and data are the mean \pm S.D. of three experiments performed in triplicate. medium by a damage of the plasma membrane. After stimulation of CBD in cell lines, it caused a significant increase in LDH release rates in a dose-dependent manner. However, LDH release in cell cultures dose not necessarily imply necrosis. Namely, plasma membrane damage is one feature of necrotic cells, and is one among other parameters to determine necrosis. According to the recent studies, there is a report that LDH release is one feature of late apoptotic cells (Grub et al., 2000). In vivo, apoptotic cell bodies are rapidly cleaned from the local tissue by macrophages (Wyllie, 1985). But, under the cell culture conditions used in this research, the apoptotic cells can not undergo rapid phagocytosis as they do in vivo in the intact tissue. Therefore, this result means to be slight discrepancy on the process of the cell death in vivo and in vitro. Apoptosis is cellular suicide or programmed cell death that is mediated by the activation of an evolutionarily conserved intracellular pathway (Bold et al., 1997; Wyllie et al., 1980; Wyllie, 1992). Apoptosis includes a feature of cell shrinkage, loss of contact with neighboring cells, formation of cytoplasmic vacuoles, plasma and nuclear membrane bubbling, DNA fragmentation and nucleic condensation (Buja et al., 1993; Buttke et al., 1994; Nicoletti et al., 1991). One of the enzymatical characteristics of the cell deaths, caspases are the important protein involved in regulating the activation of apoptic signal transmission. And caspases are divided into two classes based on the lengths of their $\mathrm{N}$-terminal prodomains, including upstream and downstream caspases (Nicholson et al., 1995). Caspase-3 is a major executor caspase with caspase- $6,-7$ at the downstream of the cell death cascade mechanism, and is activated by other initiator (caspase-9) with upstream caspase $(-2,-8,-10)$. In this research, the activation of caspase- 3 caused by CBD showed that the apoptotic signal pathway participated in CBD-induced cancer cell death. These results strongly suggest that the activation of caspase- 3 caused by CBD is responsible for inducing the cell death in cancer cells. Also, the caspase-3 induces apoptosis by caspase- 9 activity involved mitochondria pathway. After treatment with CBD, caspase-9 activity evinces that caspase-8 activated by extrinsic death ligand stimulates tBid after binding with Bid, and then stimulated tBid activates MMP in mitochondria through Bax, induces apoptosis by caspase3 , caspase- 9 to promote activation of APAF-1 through a release of cytochrome- $c$ from mitochondria at last.

As noted above, activation of caspase- $3,-8$ and -9 caused by CBD showed activations of cell death via caspase cascade in MDA-MB-231, A549 and Renca cancer cells, even though exhibited cytotoxicity in B16 mela- 
noma and SNU-C4 cells. Although CBD exhibited cytotoxicity in normal NIH3T3 cells, CBD effectively inhibited the growth of cancer cells in a dose- and time-dependent manner. These results suggest that physiological reactions of cells by CBD cause the different interaction among cells and ligand because of difference in reactive mechanism and sensitivity of cancer and normal cells. In conclusion, our present results show that CBD may be used to control cancer cells by killing them and that has the potential to perform anticancer activities. Therefore, these results suggest a possibility of anticancer agent and medical application parts on range of the biological activity of CBD. We think it is necessary to get a new viewpoint of the biological activity of $\mathrm{CBD}$ from a different angle.

\section{REFERENCES}

Andersson, D., Liu, J. J., Nilsson, A. and Duan, R. D. (2003). Ursolic acid inhibits proliferation and stimulates apoptosis in HT29 cells following activation of alkaline sphingomyelinase. Anticancer Res. 23, 3317-3322.

Asakawa, Y. (1995). "In Progress in the Chemistry of Organic Natural Products"; Herz, W., Kirby, G. W., Moore, R. E., Steglich, W. and Tamm, C. eds. Springer: Vienna, Vol : 65.

Bold, R. J., Termuhlen, P. M. and McConkey, D. J. (1997). Apoptosis, cancer and cancer therapy. Surg Oncol. 6, 133-142.

Buja, L. M., Eigenbrodt, M. L. and Eigenbrodt, E. H. (1993). Apoptosis and necrosis. Basic types and mechanisms of cell death. Arch Pathol Lab Med. 117, 1208-1214.

Buttke, T. M. and Sandstrom, P. A. (1994). Oxidative stress as a mediator of apoptosis. Immunol Today. 15, 7-10.

Carrier, E. J., Auchampach, J. A., and Hillard, C. J. (2006). Inhibition of an equilibrative nucleoside transporter by cannabidiol: a mechanism of cannabinoid immuno-suppression. Proc Natl Acad Sci U S A. 103, 7895-7900.

Casanova, M. L., Blazquez, C., Martinez-Palacio, J., Villanueva, C., Fernandez-Acenero, M. J., Huffman, J. W., Jorcano, J. L. and Guzman, M. (2003). Inhibition of skin tumor growth and angiogenesis in vivo by activation of cannabinoid receptors. $J$ Clin Invest. 111, 43-50.

Chiang, L. C., Ng, L. T., Chiang, W., Chang, M. Y. and Lin, C. C. (2003). Immunomodulatory activities of flavonoids, monoterpenoids, triterpenoids, iridoid glycosides and phenolic compounds of Plantago species. Planta Medica. 69, 600-604.

Consroe, P., Martin, A. and Singh, V. (1981). Antiepileptic potential of cannabidiol analogs. J. Clin. Pharmacol. 21, 428-436.

Consroe, P., Benedito, M. A., Leite, J. R. and Carlini, E. A., Mechoulam R. (1982). Eur J Pharmacol. 83, 293-298.

Esposito, G., De Filippis, D., Maiuri, M. C., De Stefano, D., Carnuccio, R. and luvone, T. (2006). Cannabidiol inhibits inducible nitric oxide synthase protein expression and nitric oxide production in beta-amyoid stimulated PC12 neurons through p38 MAP kinase and NF-kappaB involvement. Neurosci Lett. 399, 91-95.
Guimaraes, F. S., Chiaretti, T. M., Graeff, F. G. and Zuardi, A. W. (1990). Anti-anxiety effect of cannabidiol in the elevated plusmaze. Psychopharmacol (Berl). 100, 558-559.

Garcia-Arencibia, M., Gonzalez, S., De Lago, E., Ramos, J. A., Mechoulam, R. and Fernandez-Ruiz, J. (2007). Evaluation of the neuroprotective effect of cannabinoids in a rat model of Parkinson's disease: importance of antioxidant and cannabinoid receptor-independent properties. Brain Res. 1134, 162170.

Giudice, E. D., Rinaldi, L., Passarotto, M., Facchinetti, F., D'Arrigo, A., Guiotto, A., Carbonare, M. D., Battistin, L. and Leon, A. (2007). Cannabidiol, unlike synthetic cannabinoids, triggers activation of RBL-2H3 mast cells. J Leukoc Biol. 81, 1512-1522.

Grub, S., Persohn, E., Trommer, W. E. and Wolf, A. (2000). Mechanisms of cyclosporine A-induced apoptosis in rat hepatocyte primary cultures. Toxicol Appl Pharmacol. 163, 209220.

Hah, J. C., Rhew, T. H., Choi, E. S., Chung, H. Y. and Park, K. Y. (1992). Anti-tumor effect of ursolic acid against inbred hepatoma in CBA/J Mouse. Journal of Korean Cancer Association. 24, 790-794.

Harmand, P. O., Duval, R., Liagre, B., Jayat-Vignoles, C., Beneytout, J. L., Delage, C. and Simon, A. (2003). Ursolic acid induces apoptosis through caspase-3 activation and cell cycle arrest in HaCat cells. Int $J$ Oncol. 23, 105-112.

Kerr, J. F. R., Wyllie, A. H. and Currie, A. R. (1972). Apoptosis: a basic biological phenomenon with wide ranging implications in tissue kinetics. British Journal of Cancer. 26, 239-257.

Lee, K. H., Lim, Y. M., Wu, T. S., Zhang, D. C., Yamagishi T., Hayashi T., Hall I. H., Chang J. J. and Wu R. Y. (1988). The cytotoxic principles of Prunella vulgaris, Psychotria serpens, and Hyptis capitata: ursolic acid and related derivatives. Planta Medica. 54, 308-311.

Ligresti, A., Moriello, A. S., Starowicz, K., Matias, I., Pisanti, S., De petrocellis, L., Laezza, C., Portella, G., Bifulco, M. and Di Marzo, V. (2006). Antitumor activity of plant cannabinoid with emphasis on the effect of cannabidiol on human breast carcinoma. J Pharmacol Exp Ther. 318, 1375-1387.

Martin, B. R. (1986). Cellular effects of cannabinoids. Pharmacol Rev. 38, 45-74.

Martin, A. R., Consroe, P., Kane, V. V., Shah, V., Singh, V., Lander, N., Mechoulam, R. and Srebnik, M. (1987). Structureanticonvulsant activity relationships of cannabidiol analogs. NIDA Res Monogr. 79, 48-58.

Mckallip, R. J., Jia, W., Schlomer, J., Warren, J. W., Nagarkatti, P. S. and Nagarkatti, M. (2006). Cannabidiol-induced apoptosis in human leukemia cells: A novel role of cannabidiol in the regulation of p22phox and Nox4 expression. Mol Pharmacol. 70, 897-908.

Mosmann, T. (1983). Rapid colorimetric assay for cellular growth and survival: application to proliferation and cytotoxicity assays. J Immunol Methods. 65, 55-63.

Nicoletti, I., Migliorati, G., Pagliacci, M. C., Grignani, F. and Riccardi C. (1991). A rapid and simple method for measuring thymocyte apoptosis by propidium iodide staining and flow cytometry. J Immunol Methods. 139, 271-279.

Nicholson, D. W., Ali, A., Thomberry, N. A., Vaillancourt, J. P., 
Ding, C. D., Gallant, M., Gareau, Y., Griffin, P. R., Labelle, M. and Lazebnik, Y. A. (1995). Identification and inhibition of the ICE/CED-3 protease necessary for mammalian apoptosis. Nature. 376, 37-43.

Perry, N. B., Forster, L. M., Lorimer, S. D., May, B. C. and Weavers, R. T. (1996). Isoprenyl phenyl ethers from liverworts of the genus Trichocolea: cytotoxic activity, structural corrections, and synthesis. J. Nat. Prod. 59, 729-733.

Pertwee, R. G. (1997). Pharmacology of cannabinoid CB1 and CB2 receptors. Pharmacol Ther. 74, 129-180.

Shishodia, S., Majumdar, S., Banerjee, S. and Aggarwal, B. B. (2003). Ursolic acid inhibits nuclear factor-kappaB activation induced by carcinogenic agents through suppression of lkappaBalpha kinase and p65 phosphorylation: correlation with down-regulation of cyclooxygenase 2, matrix metalloproteinase 9, and cyclin D1. Cancer Res. 63, 4375-4383.

Soo, L. Y., Jin, D. Q., Beak, S. M., Lee, E. S. and Kim, J. A. (2003). Inhibition of ultraviolet-A-modulated signaling path- ways by asiatic acid and ursolic acid in HaCaT human keratinocytes. Eur J Pharmacol. 476, 173-178.

Vaccani, A., Massi, P., Colombo, A., Rubino, T. and Parolaro, D. (2005). Cannabidiol inhibits human glioma cell migration through a cannabinoid receptor-independent mechanism. $\mathrm{Br}$ J Pharmacol. 144, 1032-1036.

Weiss, L., Zeira, M., Reich, S., Har-Noy, M., Mechoulam, R., Slavin, S. and Gallily, R. (2006). Cannabidiol lowers incidence of diabetes in non-obese diabetic mice. Autoimmunity. 39, 143-151.

Wyllie, A. H. (1992). Apoptosis and the regulation of cell numbers in normal and neoplastic tissues: an overview. Cancer Metastasis Rev. 11, 95-103.

Wyllie, A. H. (1985). The biology of cell death in tumours. Anticancer Res. 5, 131-136.

Wyllie, A. H., Kerr, J. F. and Currie, A. R. (1980). Cell death: the significance of apoptosis. Int Rev Cytol. 68, 251-306. 